\title{
The use of legal, illegal and roll-your-own cigarettes to increasing tobacco excise taxes and comprehensive tobacco control policies: findings from the ITC Uruguay Survey
}

\author{
Dardo Curti, ${ }^{1}$ Ce Shang, ${ }^{2}$ William Ridgeway, ${ }^{3}$ Frank J Chaloupka, ${ }^{2,3,4}$ \\ Geoffrey T Fong ${ }^{5,6,7}$
}

${ }^{1}$ Centro de Investigación de la Epidemia del TabaquismoCIET, Montevideo, Uruguay ${ }^{2}$ Health Policy Center, Institute for Health Research and Policy, University of Illinois at Chicago, Chicago, Illinois, USA ${ }^{3}$ Department of Economics, University of Illinois at Chicago, Chicago, Illinois, USA ${ }^{4}$ WHO Collaborating Centre on the Economics of Tobacco and Tobacco Control

${ }^{5}$ Department of Psychology, University of Waterloo, Waterloo, Ontario, Canada ${ }^{6}$ Ontario Institute for Cancer Research, Toronto, Ontario, Canada

${ }^{7}$ School of Public Health and Health Systems, University of Waterloo, Ontario, Canada

\section{Correspondence to}

Dr Ce Shang, Health Policy Center, Institute for Health Research and Policy, University of Illinois at Chicago, 1747 W. Roosevelt Rd., Chicago, IL 60608, USA

cshang@uic.edu

Received 9 July 2014 Accepted 5 February 2015 Published Online First 4 March 2015

\section{ABSTRACT}

Background Little research has been done to examine whether smokers switch to illegal or roll-your-own (RYO) cigarettes in response to a change in their relative price. Objective This paper explores how relative prices between three cigarette forms (manufactured legal, manufactured illegal and RYO cigarettes) are associated with the choice of one form over another after controlling for covariates, including sociodemographic characteristics, smokers' exposure to antismoking messaging, health warning labels and tobacco marketing.

Methods Generalised estimating equations were employed to analyse the association between the price ratio of two different cigarette forms and the usage of one form over the other.

Findings $A 10 \%$ increase in the relative price ratio of legal to RYO cigarettes is associated with a $4.6 \%$ increase in the probability of consuming RYO cigarettes over manufactured legal cigarettes $(p \leq 0.05)$. In addition, more exposure to antismoking messaging is associated with a lower odds of choosing RYO cigarettes over manufactured legal cigarettes $(p \leq 0.05)$. Nonsignificant associations exist between the manufactured illegal to legal cigarette price ratios and choosing manufactured illegal cigarettes, suggesting that smokers do not switch to manufactured illegal cigarettes as prices of legal ones increase. However, these non-significant findings may be due to lack of variation in the price ratio measures. To improve the effectiveness of increased taxes and prices in reducing smoking, policymakers need to narrow price variability in the tobacco market.

Moreover, increasing antismoking messaging reduces tax avoidance in the form of switching to cheaper RYO cigarettes in Uruguay.

\section{INTRODUCTION}

Since ratifying the WHO Framework Convention on Tobacco Control (FCTC) in 2004, Uruguay has implemented a comprehensive set of tobacco control policies and become a world leader in the fight against tobacco. ${ }^{1-3}$ For example, Uruguay has an ad valorem tax structure based on fixed 'reference' prices that are set by the government and adjusted approximately every 6 months to keep pace with inflation. ${ }^{4-6}$ In recent years, cigarette excise taxes have risen several times via the reference price, resulting in a cigarette tax of $\$ \mathrm{U} 38$
(\$US\$2.3) ${ }^{\mathrm{i}}$ per pack of 20 sticks as of 2010. In response to rigorous control policies, tobacco usage in Uruguay has been significantly reduced. ${ }^{17-11}$

Although Uruguay's tobacco control policies appear to be comprehensive, concerns have been raised regarding tax avoidance and tax evasion that may impede the effectiveness of increased taxes in reducing tobacco use. In recent years, extensive evidence has indicated that many smokers, in particular confirmed smokers, engage in tax avoidance or evasion by switching to cheaper cigarette brands as taxes and prices increase, ${ }^{11-20}$ and reducing price gaps may incentivise smokers to trade up to higherpriced cigarettes of better quality. ${ }^{20} 21$ In addition, a handful of studies show that smokers may also switch to cheaper tobacco products (eg, roll-your-own, RYO) or different tobacco products (eg, smokeless tobacco) in response to a change in the relative price or tax..$^{22-26}$ In Uruguay, owing to its geographically small size and limited price varia-

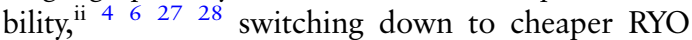
cigarettes may be a more feasible way for tax avoidance. According to the Global Adult Tobacco Survey conducted in 2009 , ${ }^{\text {iii }}$ about $32.4 \%$ of cigarette smokers in Uruguay smoke RYO cigarettes, compared with only $7.7 \%$ in its neighbour country Argentina. While Uruguay has raised its excise taxes on manufactured cigarettes multiple times since 2004, the excise taxes on RYO tobacco have remained substantially lower. Not until 2010 was the tax rate on RYO tobacco raised to $70 \%$ (compared to $28-50 \%$ in previous years) based on a reference price of \$U24.29 per $45 \mathrm{~g}$ package. $^{\text {iv }}$ (figure 1) Therefore, as excise taxes and prices of manufactured cigarettes have increased markedly, the price of RYO cigarettes has decreased to a great extent relative to manufactured cigarettes, making RYO cigarettes more appealing as an economic alternative. Accordingly, to improve the effectiveness of increasing cigarette taxes as a tobacco

${ }^{\mathrm{i}}$ According to the International Monetary Fund World Economic Outlook database, April 2013 edition, 1US\$ is approximately 17 Uruguay dollars in 2010.

${ }^{\mathrm{ii}}$ Tobacco excise taxes are imposed through fixed ad valorem rates and reference price, thus, function as specific excise taxes instead of ad valorem ones.

iii http://www.cdc.gov/tobacco/global/

${ }^{\text {iv }}$ http://www.euromonitor.com/usa 
Figure 1 Price ratio and choice of cigarette forms. RYO, roll-your-own.

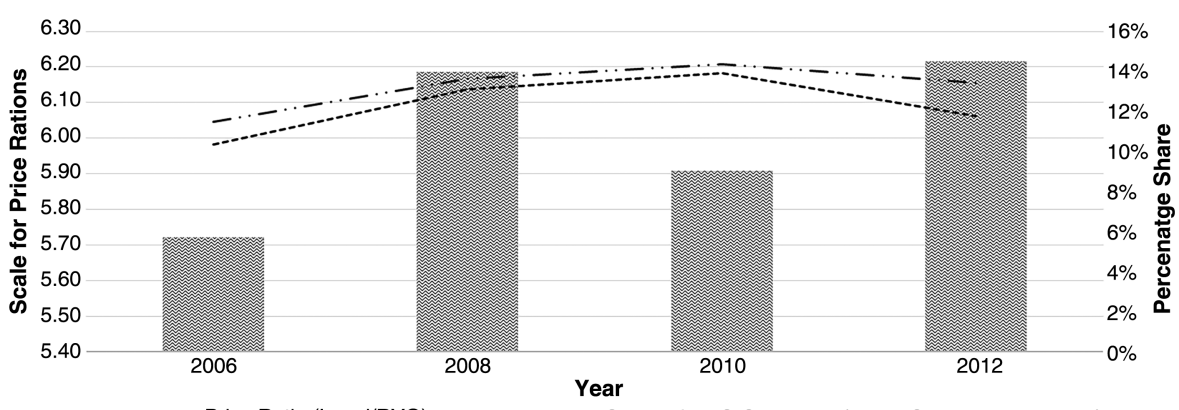

$=$ Price Ratio (Legal/RYO) - - Percentage Share of RYO Cigarettes (Illegal Cigarettes Excluded) --- Percentage Share of RYO Cigarettes (Illegal Cigarettes Included)

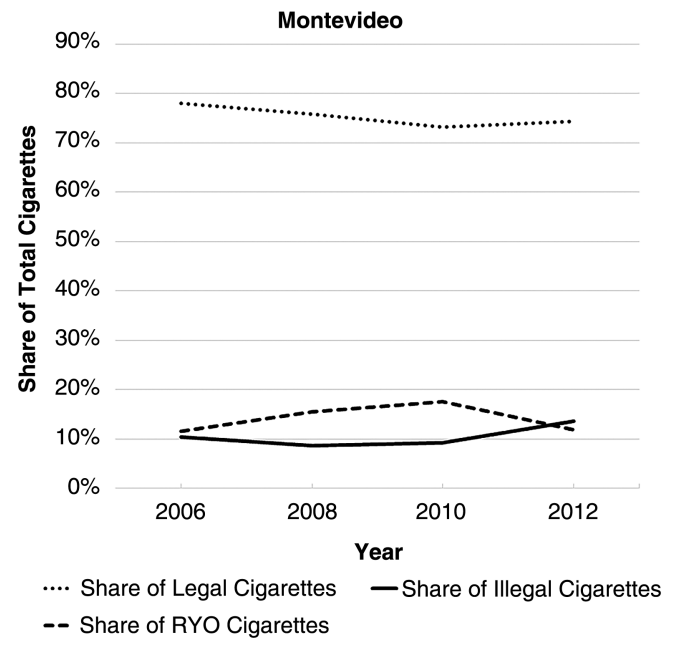

Figure 2 Shares of cigarette by form. RYO, roll-your-own.

control tool in Uruguay, studies that focus on analysing tax avoidance behaviours in the form of substitution between manufactured and RYO cigarettes are needed.

(Figure 1: International Tobacco Control (ITC) data suggest that, once based on regular use instead of last purchase, the share of 'RYO use only' among the total cigarette use was $10.2 \%$ in $2008-2009,11.6 \%$ in $2010-2011$, and $9.5 \%$ in 2012; and the share of "RYO use only and dual use of manufactured and RYO" among the total cigarette use was $28.3 \%$ in 2008-2009, 26.8\% in 2010-2011 and 23.2\% in 2012).

In addition to switching down to cheaper RYO cigarettes, smokers may also buy cheaper cigarettes in the form of manufactured illegal cigarettes. A recent study suggests that illegal cigarettes constitute $16.8 \%$ of consumption in low-income and middle-income countries. ${ }^{29}$ In Uruguay, mixed evidence has been found on the prevalence of illegal cigarettes. While contraband sales have been estimated to be $7 \%$ of total sales, ${ }^{30}$ which is relatively low compared with the world average, a recent study using ITC Uruguay data suggests that the prevalence of tax avoidance/ evasion may have been increasing in recent years. The authors of that study used the prevalence of packs without warning labels or standard warning labels as an approximation for tax avoidance/ evasion and, as of 2011, 20.5\% of packages do not carry standard-or any-warning labels; this is significantly higher than previous years. ${ }^{17}$ Analyses on the share of manufactured legal, manufactured illegal and RYO cigarettes in the Uruguayan market also suggest that its share of manufactured illegal cigarettes has been growing markedly since 2008 (figure 2), although the trends of the share of manufactured illegal cigarettes in the capital Montevideo show a somewhat different pattern than the

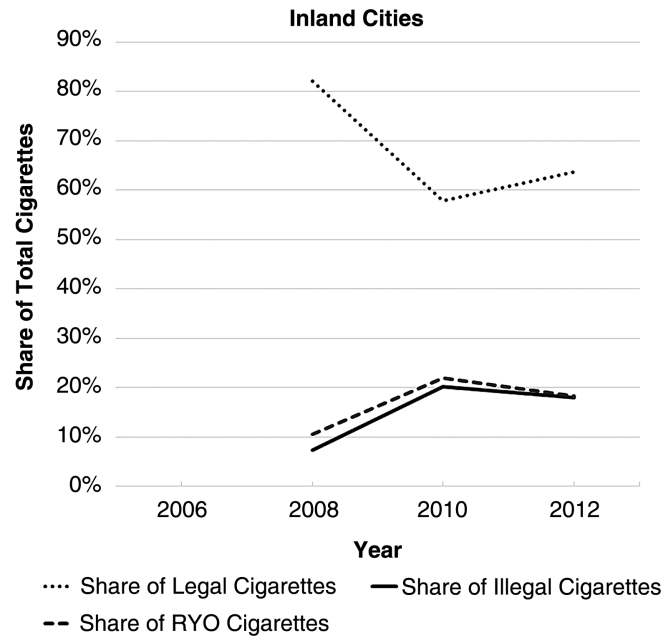

trends in inland cities (Durazno, Maldonado, Rivera and Salto). In particular, the share of manufactured illegal cigarettes in Montevideo grew from 9.3\% in 2008-2009 to $13.7 \%$ in 2012.

This paper explores how the relative prices between manufactured legal, manufactured illegal and RYO cigarettes ${ }^{\mathrm{v}}$ are associated with the use of different cigarette forms after controlling for a comprehensive set of demographic and socioeconomic characteristics and smokers' exposure to antismoking messaging, health warning labels and tobacco marketing. Specifically, it analyses how the price ratio between two cigarette forms is associated with the choice of one form over another.

\section{METHODS}

\section{Data}

Data are from the International Tobacco Control Evaluation Project (ITC) Uruguay survey, a longitudinal survey designed to evaluate the tobacco control policies advocated by the WHO FCTC. ${ }^{31}$ Sampling weights that account for survey non-response were calculated for each wave of ITC surveys. ${ }^{31} 32$ So far, four survey waves have been conducted in five Uruguayan cities: ${ }^{\mathrm{vi}}$ Montevideo, Salto, Maldonado, Durazno and Rivera. The dates of these waves were November to December 2006, September 2008 to February 2009, October 2010 to January 2011, and ${ }^{v}$ We assume all RYO cigarettes are legal because their cheap prices may
be a disincentive for smuggling or illegal trade, though only legally
obtained manufactured products are referred to as legal in this paper.
vi In wave 1 , the only city surveyed was Montevideo. Other cities were
added in later waves. 
September to December 2012. Adult smokers aged 18 years or older were interviewed and their tobacco consumption, tobacco purchase information, exposure to tobacco control policies, exposure to tobacco marketing as well as socioeconomic and demographic characteristics were collected. In particular, the price per cigarette or per pack was derived from the last purchase information. Detailed brand information was used to identify the purchase/use of manufactured legal, manufactured illegal and RYO cigarettes. The average retention rate of the survey was approximately $70 \% .^{33}$ The wave 1 survey included approximately 900 respondents from Montevideo. With replenishment, approximately 1000 respondents in Montevideo and 400 respondents in each of the other four cities were followed up in waves $2-4$. By wave 4 , around $16 \%$ of smokers had quit.

The tobacco market of Uruguay is an oligopoly dominated by three companies: Cía Industrial de Tabacos Monte Paz SA, Philip Morris International Inc and British American Tobacco Plc share $99 \%$ of the legal market, with the domestic company Monte Paz being the biggest player. ${ }^{34} 35$ Therefore, any brands that are not owned by these three companies are most likely products from illegal trade, and so are categorised as manufactured illegal cigarettes in this study. A majority of the brands classified as illegal were from Paraguay.

Since the brand of the last purchase was used to define the cigarette form, dual use and the concurrent use of multiple cigarette forms cannot be identified using this approach. The sample used for analysis was restricted to smokers who reported the use of one of the three defined forms: manufactured legal, manufactured illegal and RYO cigarettes (for the latter, there is no distinction between legal or illegal status). Stratified multistage design was employed in the survey with sections in each city that correspond to census tracts used as primary strata. Each section was thereafter divided into segments, and then further into units.

\section{Variables}

Four dichotomous dependent variables were constructed to measure smokers' choice of one cigarette form over another, including the choice of RYO cigarettes over manufactured illegal and legal cigarettes, the choice of RYO cigarettes over manufactured legal cigarettes (respondents who used manufactured illegal cigarettes were dropped out of the sample), the choice of RYO cigarettes over manufactured illegal cigarettes (respondents who used manufactured legal cigarettes were dropped out of the sample), and the choice of manufactured illegal over legal cigarettes (respondents who reported RYO cigarette use were dropped out of the sample). These four outcomes were analysed separately on how they are associated with relative price ratios between products, exposure to the tobacco control and marketing environment, and sociodemographic characteristics.

Self-reported prices and exposure to tobacco control policies and tobacco marketing are most likely simultaneously determined with tobacco use behaviours. For example, heavier smokers are more likely to buy cheaper cigarettes. Thus, using self-reported measures of tobacco control policies may lead to an overestimation of the negative association between tobacco control policies and smoking. Meanwhile, coupons, delivery cost and other costs involved in the distribution chain in different locations are likely to vary and most likely lead to exogenous differences in prices by locations. Therefore, to address this simultaneity bias, many previous studies and methodology discussions have suggested analysing aggregated measures of selfreported prices and policy/marketing exposure..$^{7-10} \quad 36 \quad 37$ Moreover, only the price of the purchased product was reported by individuals and aggregating prices is necessary to estimate the prices of other products faced by individuals who live in the same location. For the above reasons, price and exposure measures in this study were constructed by aggregating at the segment level, which means that the price is less likely to be endogenous.

Standardised prices ${ }^{\mathrm{vii}}$ of manufactured illegal, manufactured legal and RYO cigarettes per stick were constructed using median prices by cigarette form, survey wave and segment. For RYO cigarettes, it was assumed that each 'pouch' or 'container' of tobacco provides 72 cigarettes since a standard pouch in Uruguay contains $45 \mathrm{~g}$ of tobacco and previous studies indicate that 20 cigarettes are equivalent to approximately $12.5 \mathrm{~g}$ of loose tobacco. ${ }^{38}$ Thus, a standard pouch is approximately 3.6 packs or 72 sticks of cigarettes. In addition, since the prevalence of manufactured illegal and RYO cigarette use is relatively low, the aggregated prices of these two cigarette forms are not always available for all segments during the survey period. On average, among a total number of 289 segments (around 20 observations per segment), 7 segments were missing prices of manufactured legal cigarettes, 139 segments were missing prices of manufactured illegal cigarettes and 154 segments were missing prices of RYO cigarettes. Therefore, prices of manufactured legal, manufactured illegal and RYO cigarettes were first predicted for each individual in each wave after regressing these prices on strata (division) fixed effects and survey-wave fixed effects, then these predicted prices were aggregated to the segment level using median prices, and in the final step these aggregated predicted prices replaced missing segment-level prices. Doing this utilised the national increment in tobacco prices over the years and strata-specific attributes in tobacco prices to fill in missing prices. The mean minimum to maximum range and SDs of prices before and after filling in missing values were very close. ${ }^{\text {viii }}$ Price ratios between cigarette forms, including the price ratio of manufactured legal to RYO cigarettes, price ratio of manufactured illegal to RYO cigarettes and price ratio of manufactured legal to illegal cigarettes, were thereafter generated using the corresponding segment-level prices after filling in missing values.

Exposure measures were constructed in the form of indices. In ITC surveys, respondents were asked to report their recent exposure to antismoking messaging in a list of venues (television, radio, papers, posters, bus, billboards, street vendors, stores, restaurants, entertainment venues, supermarkets, bookstores, cinemas and cigarette packs), exposure to tobacco marketing in a list of venues for advertising and promotion (television, radio, papers, posters, bus, billboards, street vendors, stores, coffee shops, discos, supermarket, bookstores, cinemas, sport event, art event, samples, special price offers, gift, logo clothing, email, mail and received mails). Indices were developed by first estimating, for each respondent, the fraction of venues that the respondent has been exposed to, and aggregating these individual-level indices to the segment level using mean indices. The warning label index was constructed at the segment level as the mean of respondents' frequency of noticing

\footnotetext{
${ }^{\text {vii }}$ Price data included data for single cigarettes, packs and cartons. When possible, cartons and packages were disaggregated into single cigarettes using information provided by respondents on the number of packs in a carton and the number of cigarettes in a pack. When this information was not available, it was assumed that there are 10 packs in a carton and 20 cigarettes in a pack.

${ }^{\text {viii }}$ Two-sample $t$ test suggests that the means for prices before and after filling in missing values are not significantly different.
} 
warning labels (1, never; 2 , once in a while; 3 , often; 4 , very often). All indices other than the warning label index were scaled by multiplying by a factor of ten.

The socioeconomic and demographic characteristics include gender, age (4 categories: referent 18-24, 25-39, 40-54, and $\geq 55$ years), highest education achieved (four categories: $<$ middle school-referent, middle school, high school, and $>$ high school), household monthly income ${ }^{\mathrm{ix}}$ (five categories: \$U0-\$U4500-referent, \$U4501-\$U8000，\$U8001-\$U15 000, $>$ \$U15 000, and income is missing), and marital status (four categories: married- referent, separated/divorced/widowed, single and domestic partnership).

\section{Models}

Given that the ITC Uruguay survey is longitudinal, to account for intertemporal correlation, generalised estimating equations (GEE) were used. ${ }^{32}$ GEE models extend generalised linear models by adjusting for the correlated data. ${ }^{39}$ Logistic link, a binomial family and exchangeable correlation are applied in estimating the model, which can be described in the equation below:

$$
\mathrm{T}_{\mathrm{it}}=\beta_{0}+\beta_{1} \text { Price_ratio }_{\mathrm{st}}+\beta_{2} \text { Environment }_{\mathrm{st}}+\beta_{3} \mathrm{X}_{\mathrm{it}}+\text { Year }_{\mathrm{t}}
$$

where Environment st $_{\text {is }}$ a vector of segment-level variables that measure exposure to tobacco marketing and tobacco control policies such as warning labels and antismoking messaging, $\mathrm{X}_{\mathrm{it}}$ is a vector of individual-level socioeconomic and demographic characteristics, and Year $_{t}$ is a vector of survey-wave fixed effects with wave 1 (year 2006) omitted. The covariates also include a dichotomous indicator for respondents surveyed in Montevideo, which appears in all waves.

To carry out the analyses, the four dichotomised choice outcomes $\left(T_{i t}\right)$ defined in the variable section were linked to their corresponding price ratios (Price_ratio ${ }_{\text {st }}$ ). Specifically, RYO versus others (manufactured legal and illegal cigarettes combined) and RYO cigarettes versus manufactured legal cigarettes are linked to the price ratio of manufactured legal to RYO cigarettes; RYO cigarettes versus manufactured illegal cigarettes are linked to the price ratio of manufactured illegal to RYO cigarettes; and manufactured illegal versus legal cigarettes are linked to the price ratio of manufactured legal to illegal cigarettes. All summary statistics and regressions were weighted using sampling weights. Robust SEs clustered at the segment level were obtained through the analysis.

\section{RESULTS}

Tables 1 and 2 report the variable definition and weighted summary statistics after adjusting for the inter-temporal correlation in the longitudinal survey. Among all users, 12.4\% reported using RYO cigarettes. When the use of manufactured illegal cigarettes is excluded, 14\% reported choosing RYO cigarettes over manufactured legal cigarettes; and when RYO use is excluded, $12.8 \%$ reported choosing manufactured illegal over legal cigarettes. ${ }^{\mathrm{x}}$ Among all users who do not use manufactured legal cigarettes, $52.5 \%$ reported choosing RYO cigarettes over manufactured illegal cigarettes. Price ratio estimates indicate that

\footnotetext{
${ }^{\mathrm{ix}}$ In wave 1 , the five categories are \$U0-\$U3500-referent, \$U3501\$U7000, \$U7001-\$U10 000, \$U100 001-\$U15 000, and missing income.

${ }^{\mathrm{x}}$ These are essentially percentages imputed using RYO use/RYO or legal use and illegal use/illegal or legal use.
}

the price of manufactured legal cigarettes is about 6 times the price of RYO cigarettes and 2.5 times the price of manufactured illegal cigarettes, while the price of manufactured illegal cigarettes is 2.7 times the price of RYO cigarettes. The sociodemographic characteristics of the four samples are very similar, except that the sample consisting of only manufactured illegal and RYO cigarette users (column 3 ) shows lower education and income levels. A majority of statistics shows that around $60 \%$ of the respondents have either a middle or high school degree, $35 \%$ have an annual household income more than \$U15 000, $60 \%$ are between ages 25 and 54, and 35\% are married.

Results from regression analyses are reported in table 3 . The effects of price ratios are also shown in elasticities. The estimates indicate that a higher price of manufactured legal cigarettes relative to RYO cigarettes is associated with an increased use of RYO cigarettes over other cigarettes, and a $10 \%$ increase in the relative price ratio of manufactured legal to RYO cigarettes is associated with a $4.6 \%$ increase in the probability of consuming RYO cigarettes over manufactured legal cigarettes. Relative price ratios pertaining to manufactured illegal cigarettes were not found to be significantly associated with the choice of manufactured illegal cigarettes.

It is worth noting that more exposure to antismoking messaging reduces RYO consumption relative to the consumption of manufactured legal or illegal cigarettes. Given that a significant portion of Uruguayan smokers think RYO cigarettes are less harmful than manufactured cigarettes, this negative association most likely reflects the increase in the percentage of smokers who consider RYO and manufactured cigarettes to be equally harmful. This group increased from 35\% of smokers in 2006 to $40 \%$ in 2010-2012, in part as a result of a comprehensive antismoking campaign launched in 2006 that treats RYO and manufactured cigarettes the same way. Exposure to warning labels and marketing was not found to be significantly associated with cigarette choices.

Smokers who are male, lower than middle-school educated, with a monthly household income of \$U4500 or lower, and age 40 or older are more likely to choose RYO cigarettes over manufactured legal products. Smokers who are lower than middleschool educated, with a monthly household income of \$U4500 or lower, and older than the age of 18-24 years are more likely to choose manufactured illegal over legal cigarettes. In general, education, age, income and marital status do not appear to be significantly associated with the choice between manufactured illegal and RYO cigarettes. In addition, the higher smokers' education and income are, the less likely they are to choose RYO or manufactured illegal cigarettes over manufactured legal cigarettes. The older smokers are, the more likely they are to choose $\mathrm{RYO}$ or manufactured illegal cigarettes over manufactured legal ones.

\section{DISCUSSION AND CONCLUSION}

The results of this study suggest that a higher price of manufactured legal cigarettes relative to RYO cigarettes is associated with an increased use of RYO cigarettes over other cigarettes. A $10 \%$ increase in the relative price ratio is associated with a $4.6 \%$ increase in the probability of consuming RYO cigarettes over manufactured legal cigarettes. Therefore, it is necessary to narrow price gaps between RYO cigarettes and manufactured legal cigarettes to decrease the odds of smokers switching from manufactured legal cigarettes to RYO cigarettes for tax avoidance. In contrast, a non-significant association between price ratios and choosing manufactured illegal cigarettes suggests that smokers do not switch to manufactured illegal cigarettes as 
Table 1 Variable descriptions

\begin{tabular}{|c|c|c|}
\hline \multicolumn{2}{|l|}{ Variables/indicators } & Description \\
\hline \multicolumn{3}{|c|}{ Segmental-level price ratio variables } \\
\hline \multicolumn{2}{|c|}{ Price manufacture legal/price RYO } & The ratio of segmental-level price of manufactured legal cigarettes to the segmental-level price of RYO cigarettes \\
\hline \multicolumn{2}{|c|}{ Price manufacture illegal/price RYO } & The ratio of segmental-level price of manufactured illegal cigarettes to the segmental-level price of RYO cigarettes \\
\hline \multicolumn{2}{|c|}{ Price manufacture legal/price manufacture illegal } & $\begin{array}{l}\text { The ratio of segmental-level price of manufactured legal cigarettes to the segmental-level price of manufactured illegal } \\
\text { cigarettes }\end{array}$ \\
\hline \multicolumn{3}{|c|}{ Segmental-level policy exposure index } \\
\hline \multicolumn{2}{|l|}{ Antismoking } & $\begin{array}{l}\text { The segmental-level average of individuals' exposure to antismoking messaging ranges from } 1 \text { to } 10 \text {. Individuals' } \\
\text { exposure were measured using the fraction that he/she was exposed to out of a number of antismoking broadcasting } \\
\text { venues (TV, radio, etc.), then was multiplied by } 10\end{array}$ \\
\hline \multicolumn{2}{|l|}{ Warning labels } & $\begin{array}{l}\text { The segmental-level average of individuals' exposure to warning labels in the past month }(1, \text { never; } 2 \text {, rarely; } 3 \text {, } \\
\text { sometimes; } 4 \text {, often; } 5 \text {, very often) ranges from } 1 \text { to } 5\end{array}$ \\
\hline \multicolumn{2}{|l|}{ Marketing } & $\begin{array}{l}\text { The segmental-level average of individuals' exposure to tobacco advertisements and promotion ranges from } 1 \text { to } 10 \text {. } \\
\text { Individuals' exposure was measured using the fraction that he/she was exposed to out of a number of venues } \\
\text { (TV, radio, etc), then was multiplied by } 10\end{array}$ \\
\hline \multicolumn{3}{|l|}{ Individual-level variables } \\
\hline \multicolumn{2}{|r|}{ RYO $=1$, others $=0$} & Indicator equals 1 if cigarette is RYO, 0 for all other types \\
\hline $\begin{array}{l}\text { RYO or legally } \\
\text { manufactured }\end{array}$ & $\begin{array}{l}\text { RYO }=1 \text {, legal }=0 \text {, } \\
\text { illegal }=\text {. }\end{array}$ & Indicator equals 1 if cigarette is RYO, 0 if it is a legally manufactured cigarette \\
\hline $\begin{array}{l}\text { RYO or illegally } \\
\text { manufactured }\end{array}$ & $\begin{array}{l}\text { RYO }=1 \text {, illegal }=0 \text {, } \\
\text { legal }=.\end{array}$ & Indicator equals 1 if cigarette is RYO, 0 if it is an illegally manufactured cigarette \\
\hline $\begin{array}{l}\text { Illegally or legally } \\
\text { manufactured }\end{array}$ & $\begin{array}{l}\text { Illegal=1, legal }=0 \text {, } \\
\text { RYO==. }\end{array}$ & Indicator equals 1 if cigarette is an illegally manufactured cigarette, 0 if it is a legally manufactured cigarette \\
\hline Gender & Male & Indicator equals 1 if respondent is male, 0 if respondent is female \\
\hline Education & $\begin{array}{l}<\text { Middle school } \\
\text { Middle school } \\
\text { High school } \\
>\text { High school }\end{array}$ & $\begin{array}{l}\text { Indicator equals } 1 \text { if respondent has less than middle school education, } 0 \text { otherwise } \\
\text { Indicator equals } 1 \text { if respondent's highest level of completed education is middle school, } 0 \text { otherwise } \\
\text { Indicator equals } 1 \text { if respondent's highest level of education is completed or uncompleted high school, technical } \\
\text { school, teaching school or army/police training, } 0 \text { otherwise } \\
\text { Indicator equals } 1 \text { if respondent's highest level of education is completed or uncompleted university attendance, } \\
0 \text { otherwise }\end{array}$ \\
\hline Income & $\begin{array}{l}\text { \$U0-\$U4500 } \\
\$ U 4501-\$ U 8000 \\
\$ U 8001-\$ U 15000 \\
>\$ U 15000 \\
\text { Missing }\end{array}$ & $\begin{array}{l}\text { Indicator equals } 1 \text { if respondent's annual household income is less than } \$ U 4500,0 \text { otherwise } \\
\text { Indicator equals } 1 \text { if respondent's annual household income is } \$ \cup 4501-\$ U 8000,0 \text { otherwise } \\
\text { Indicator equals } 1 \text { if respondent's annual household income is } \$ U 8001-\$ U 15000,0 \text { otherwise } \\
\text { Indicator equals } 1 \text { if respondent's annual household income is greater than } \$ U 15000,0 \text { otherwise } \\
\text { Indicator equals } 1 \text { if respondent's annual household income is not reported, } 0 \text { otherwise }\end{array}$ \\
\hline Age & $\begin{array}{l}18-24 \\
25-39 \\
40-54 \\
55+\end{array}$ & $\begin{array}{l}\text { Indicator equals } 1 \text { if respondent's age is } 18-24,0 \text { otherwise } \\
\text { Indicator equals } 1 \text { if respondent's age is } 25-39,0 \text { otherwise } \\
\text { Indicator equals } 1 \text { if respondent's age is } 40-54,0 \text { otherwise } \\
\text { Indicator equals } 1 \text { if respondent's age is } 55 \text { or above, } 0 \text { otherwise }\end{array}$ \\
\hline Marital status & $\begin{array}{l}\text { Married } \\
\text { Separated/divorced/ } \\
\text { widowed } \\
\text { Domestic partnership } \\
\text { Single }\end{array}$ & $\begin{array}{l}\text { Indicator equals } 1 \text { if respondent is married, } 0 \text { otherwise } \\
\text { Indicator equals } 1 \text { if respondent is separated, divorced or widowed, } 0 \text { otherwise } \\
\text { Indicator equals } 1 \text { if respondent is in a domestic partnership, } 0 \text { otherwise } \\
\text { Indicator equals } 1 \text { if respondent is single, } 0 \text { otherwise }\end{array}$ \\
\hline \multicolumn{3}{|l|}{ Fixed effects } \\
\hline \multicolumn{2}{|l|}{ Montevideo indicator } & Indicator equals 1 if observation is from Montevideo, 0 for the other cities \\
\hline \multicolumn{2}{|l|}{ Wave 1 indicator } & Indicator equals 1 for observation from first wave, 0 for other waves \\
\hline \multicolumn{2}{|l|}{ Wave 2 indicator } & Indicator equals 1 for observation from second wave, 0 for other waves \\
\hline \multicolumn{2}{|l|}{ Wave 3 indicator } & Indicator equals 1 for observation from third wave, 0 for other waves \\
\hline \multicolumn{2}{|l|}{ Wave 4 indicator } & Indicator equals 1 for observation from fourth wave, 0 for other waves \\
\hline
\end{tabular}

Wave 1 income is coded differently than waves 2-4. Wave 1 uses the containers 'Up to \$U 3500,' '\$U3501 to \$U7000,' '\$U7001 to \$U10 000,' '\$U10 001 to \$U15 000.' Waves 2-4 use 'Up to \$U 4500,' '\$U4501 to \$8000,' '\$U8001 to \$U12 500,' '\$U12 501 to \$U15 000.'

RYO, roll-your-own.

prices of legal ones increase. The combined evidence suggests that, as prices increase, consumers in Uruguay are most likely to engage in tax avoidance by switching to RYO cigarettes rather than by switching to manufactured illegal cigarettes.

Although the evidence indicates that smokers do not substitute manufactured legal with illegal cigarettes as prices increase, figure 2 shows an increasing trend of manufactured illegal cigarette use in 2012 for Montevideo. Given that a majority of the study sample is from Montevideo, where the prevalence of manufactured illegal cigarettes is lower than inland cities that share a border with other countries, it is likely that Montevideo residents had less access to illegal cigarettes, and thus did not respond to price increases by switching to manufactured illegal cigarettes. If the illegal cigarette supply keeps growing in Montevideo, smokers there may be more likely to switch to illegal cigarettes. Therefore, it is important to increase surveillance of illegal cigarettes, especially in Montevideo.

More exposure to antismoking messaging is associated with a greater consumption of manufactured legal cigarettes at the expense of RYO cigarettes. Given that a significant percentage of Uruguayan smokers think RYO cigarettes are less harmful than manufactured cigarettes, smokers who are exposed to 
Table 2 Descriptive statistics of four samples, International Tobacco Control Uruguay waves 1-4

\begin{tabular}{|c|c|c|c|c|c|}
\hline & & \multicolumn{4}{|c|}{ Sample components } \\
\hline \multicolumn{6}{|c|}{ Segmental-level price ratio variables } \\
\hline \multicolumn{2}{|c|}{ Price manufacture legal/price RYO } & $6.023(2.251)$ & $5.996(2.127)$ & & \\
\hline \multicolumn{2}{|c|}{ Price manufacture illegal/price RYO } & & & $2.704(1.349)$ & \\
\hline \multicolumn{2}{|l|}{ Antismoking } & $5.368(0.041)$ & $5.384(0.043)$ & $5.292(0.082)$ & $5.375(0.046)$ \\
\hline \multicolumn{2}{|l|}{ Warning labels } & $2.851(0.012)$ & $2.851(0.013)$ & $2.848(0.022)$ & $2.853(0.013)$ \\
\hline & $4.421(0.037)$ & $4.458(0.039)$ & $4.257(0.077)$ & $4.427(0.041)$ \\
\hline Individual-level variables & Indicators & & & & \\
\hline \multicolumn{2}{|r|}{$\mathrm{RYO}=1$, others $=0$} & $0.124(0.330)$ & & & \\
\hline Education & $\begin{array}{l}<\text { Middle school } \\
\text { Middle school } \\
\text { High school } \\
\text { > High school }\end{array}$ & $\begin{array}{l}0.258(0.012) \\
0.351(0.013) \\
0.254(0.011) \\
0.139(0.009)\end{array}$ & $\begin{array}{l}0.238(0.013) \\
0.357(0.013) \\
0.262(0.011) \\
0.147(0.010)\end{array}$ & $\begin{array}{l}0.474(0.029) \\
0.299(0.024) \\
0.184(0.020) \\
0.043(0.010)\end{array}$ & $\begin{array}{l}0.226(0.012) \\
0.359(0.013) \\
0.264(0.012) \\
0.154(0.010)\end{array}$ \\
\hline Income & $\begin{array}{l}\text { \$U0-\$U4500 } \\
\text { \$U4501-\$U8000 } \\
\text { \$U8001-\$U15000 } \\
\text { > \$U15 000 } \\
\text { Missing }\end{array}$ & $\begin{array}{l}0.118(0.008) \\
0.177(0.008) \\
0.275(0.010) \\
0.344(0.011) \\
0.087(0.006)\end{array}$ & $\begin{array}{l}0.106(0.008) \\
0.174(0.009) \\
0.271(0.010) \\
0.361(0.012) \\
0.088(0.007)\end{array}$ & $\begin{array}{l}0.222(0.020) \\
0.227(0.017) \\
0.282(0.021) \\
0.190(0.018) \\
0.073(0.012)\end{array}$ & $\begin{array}{l}0.097(0.008) \\
0.166(0.009) \\
0.278(0.011) \\
0.369(0.012) \\
0.088(0.007)\end{array}$ \\
\hline Age & $\begin{array}{l}18-24 \\
25-39 \\
40-54 \\
55+\end{array}$ & $\begin{array}{l}0.180(0.010) \\
0.328(0.013) \\
0.291(0.012) \\
0.193(0.011)\end{array}$ & $\begin{array}{l}0.189(0.011) \\
0.335(0.013) \\
0.279(0.013) \\
0.187(0.012)\end{array}$ & $\begin{array}{l}0.096(0.015) \\
0.311(0.025) \\
0.335(0.026) \\
0.254(0.024)\end{array}$ & $\begin{array}{l}0.194(0.011) \\
0.332(0.013) \\
0.290(0.013) \\
0.177(0.011)\end{array}$ \\
\hline
\end{tabular}

more antismoking information may be more aware of the risk of RYO cigarettes and less likely to use them. Thus, exposure to antismoking messaging appears to help reduce the prevalence of RYO cigarettes over other cigarette use, reducing tax avoidance.

In sum, to improve the effectiveness of raising taxes in reducing smoking, policymakers should aim to narrow price variability and price gaps between products in a tobacco market. In Uruguay, although the 2010 tax increase on RYO cigarettes narrowed the price gap between manufactured legal and RYO cigarettes, the prices of manufactured legal cigarettes have grown faster than the prices of RYO cigarettes during 2010-2012. Thus, a more aggressive tax increase on RYO cigarettes is needed to reduce the price gap. Additionally, increasing the coverage of antismoking messaging will further reduce tax avoidance in the form of switching to cheap RYO cigarettes in Uruguay.

This study is subject to several limitations. First, it used the brand information from the last purchase to identify the use of cigarettes in different forms, and thus could not identify dual or concurrent use of multiple cigarette forms. Therefore, the prevalence of manufactured illegal cigarettes may be underestimated if manufactured illegal cigarettes are purchased less frequently than legal ones or RYO ones. In addition, it is possible that participants under-report the purchase of illegal cigarettes due to legal concerns, which may bias the results pertaining to manufactured illegal cigarettes. Second, divisionlevel price information was used to predict missing segment-level prices of RYO and manufactured illegal cigarettes, which may result in a limited variation in the segment-level prices of RYO and manufactured illegal cigarettes, and thus nonsignificant results for the association between price ratios and the use of manufactured illegal cigarettes. Third, all brands that do not belong to the big three tobacco companies were characterised as manufactured illegal cigarettes, which may not be obtained through illegal trade. However, given that the three companies together share $99 \%$ of the legal market ${ }^{35}$ and most illegal cigarette brands were from Paraguay, this measurement error is limited. Fourth, aggregated policy and price measures were used that could be subject to endogeneity bias induced by segment-level unobserved marketing, messaging and pricing factors.

Despite these limitations, this study contributes to the existing literature on providing evidence on the substitution between manufactured legal, manufactured illegal and RYO cigarettes in 
Table 3 Binomial generalised estimating equation models, choice between legal, illegal and RYO cigarettes

\begin{tabular}{|c|c|c|c|c|}
\hline Variable & $\begin{array}{l}\text { Binomial model } 1 \\
\text { RYO }=1 \text {, others }=0\end{array}$ & $\begin{array}{l}\text { Binomial model } 2 \\
\text { RYO=1, legal=0, illegal=. }\end{array}$ & $\begin{array}{l}\text { Binomial model } 3 \\
\text { RYO=1, illegal=0, legal=. }\end{array}$ & $\begin{array}{l}\text { Binomial model } 4 \\
\text { Illegal }=1 \text {, legal }=0, R Y 0==\end{array}$ \\
\hline \multicolumn{5}{|l|}{ Price ratio variables } \\
\hline Price manufactured-legal/price RYO & $1.069 * *$ (1.01 to 1.132$)$ & - & - & - \\
\hline Price manufactured-legal/price RYO & - & $1.095^{* *}(1.016$ to 1.18$)$ & - & - \\
\hline Price manufactured-illegal/price RYO & - & - & $1.052(0.905$ to 1.223$)$ & - \\
\hline Price manufactured-legal/illegal & - & - & - & 1.024 (0.96 to 1.092$)$ \\
\hline Price ratio elasticity & $0.344^{* * *}(0.096$ to 0.591$)$ & $0.459^{* * *}(0.193$ to 0.725$)$ & $0.065(-0.061$ to 0.191$)$ & $0.050(-0.097$ to 0.196$)$ \\
\hline \multicolumn{5}{|l|}{ Policy exposure index } \\
\hline Antismoking & $0.899 * *(0.821$ to 0.984$)$ & $0.913^{* *}(0.836$ to 0.997$)$ & $0.898(0.765$ to 1.055$)$ & $1.089(0.974$ to 1.218$)$ \\
\hline Warning labels & 0.979 (0.76 to 1.261$)$ & $0.984(0.764$ to 1.267$)$ & $0.993(0.694$ to 1.421$)$ & $0.943(0.718$ to 1.238$)$ \\
\hline Marketing & $1.064(0.959$ to 1.18$)$ & $1.051(0.942$ to 1.173$)$ & 1.027 (0.876 to 1.204$)$ & 0.981 (0.86 to 1.119$)$ \\
\hline Number of observations & 4197 & 3726 & 994 & 3674 \\
\hline \multicolumn{5}{|l|}{ Demographic variables } \\
\hline Gender: female & 1 & 1 & 1 & 1 \\
\hline Gender: male & $4.145^{* * *}(2.953$ to 5.818$)$ & $3.826^{* * *}(2.683$ to 5.455$)$ & $5.564^{* * *}(3.545$ to 8.733$)$ & $0.793(0.566$ to 1.111$)$ \\
\hline Education: <middle school & 1 & 1 & 1 & 1 \\
\hline Education: middle school & $0.509^{* * *}(0.311$ to 0.832$)$ & $0.459^{* * *}(0.282$ to 0.746$)$ & $0.832(0.416$ to 1.665$)$ & $0.465^{* * *}(0.295$ to 0.733$)$ \\
\hline Education: high school & $0.477^{* * *}(0.292$ to 0.779$)$ & $0.414^{* * *}(0.257$ to 0.668$)$ & 0.841 (0.456 to 1.55$)$ & $0.441^{* * *}(0.284$ to 0.684$)$ \\
\hline Education: >high school & $0.219^{* * *}$ (0.113 to 0.424$)$ & $0.200^{* * *}(0.103$ to 0.387$)$ & $0.526(0.164$ to 1.692$)$ & $0.290^{* * *}(0.148$ to 0.568$)$ \\
\hline Age $18-24$ & 1 & 1 & 1 & 1 \\
\hline Age $25-39$ & 1.409 (0.787 to 2.522$)$ & 1.325 (0.719 to 2.442$)$ & 0.887 (0.41 to 1.92$)$ & $1.693^{* *}(1.035$ to 2.769$)$ \\
\hline Age $40-54$ & $1.775^{*}(0.952$ to 3.31$)$ & $1.767^{*}(0.94$ to 3.321$)$ & 0.831 (0.393 to 1.757$)$ & $3.016^{* * *}(1.718$ to 5.293$)$ \\
\hline Age $55+$ & $2.254^{* *}(1.164$ to 4.363$)$ & $2.208^{* *}(1.11$ to 4.393$)$ & $0.844(0.373$ to 1.907$)$ & $2.776^{* * *}(1.417$ to 5.437$)$ \\
\hline Income: \$U0-\$U4500 & 1 & 1 & 1 & 1 \\
\hline Income: \$U4501-\$U8000 & 0.719 (0.435 to 1.188$)$ & $0.690(0.424$ to 1.122$)$ & $0.857(0.447$ to 1.643$)$ & $0.504^{* * *}(0.318$ to 0.799$)$ \\
\hline Income: \$U8001-\$U15 000 & $0.526^{* *}(0.302$ to 0.916$)$ & $0.474^{* * *}(0.273$ to 0.822$)$ & $0.689(0.315$ to 1.509$)$ & $0.497^{* * *}(0.3$ to 0.824$)$ \\
\hline Income: >\$U15 000 & $0.321^{* * *}(0.179$ to 0.575$)$ & $0.288^{* * *}(0.165$ to 0.503$)$ & $0.705(0.315$ to 1.578$)$ & $0.263^{* * *}(0.159$ to 0.435$)$ \\
\hline Income: missing & $0.656(0.321$ to 1.339$)$ & $0.635(0.3$ to 1.343$)$ & $0.750(0.358$ to 1.57$)$ & $0.510^{* *}(0.262$ to 0.991$)$ \\
\hline Marital: married & 1 & 1 & 1 & 1 \\
\hline Marital: Separated/divorced/widowed & $0.652 *(0.397$ to 1.071$)$ & $0.674(0.392$ to 1.148$)$ & 0.661 (0.361 to 1.209$)$ & $1.167(0.767$ to 1.775$)$ \\
\hline Marital: domestic partnership & 1.425 (0.817 to 2.486$)$ & 1.491 (0.858 to 2.591$)$ & 1.247 (0.687 to 2.263$)$ & $1.467^{*}(0.987$ to 2.18$)$ \\
\hline Marital: single & 0.992 (0.579 to 1.701$)$ & 1.030 (0.598 to 1.773$)$ & 1.081 (0.554 to 2.109$)$ & $1.029(0.619$ to 1.71$)$ \\
\hline \# of observations & 4197 & 3726 & 994 & 3674 \\
\hline
\end{tabular}

Note: all regressions are weighted using sample weights and also contain control Montevideo dummy and dummies for years 2008-2009 (wave2), $2010-2011$ (wave3) and 2012 (wave 4), and indicator for residents from Montevideo. Robust SEs clustered at the segment level are obtained.

${ }^{*} \mathrm{p} \leq 0.1,{ }^{* *} p \leq 0.05,{ }^{* *} \mathrm{p} \leq 0.01$. ORs and elasticities are reported and $95 \%$ Cls are in parentheses. OR=exp(b), b is the coefficient. Elasticity=the average of $d(\log y) / d($ log $x)$.

RYO, roll-your-own.

response to a change in relative prices, which has not been well studied. Its results suggest that increasing price ratios or price gaps are associated with switching to cheaper cigarette forms. Therefore, to improve the effectiveness of increasing taxation as

\section{What this paper adds}

- Using Uruguay data, this paper provides evidence on substitution between manufactured legal, manufactured illegal and roll-your-own (RYO) cigarettes in response to changes in their relative prices.

- A $10 \%$ increase in the relative price ratio of manufactured legal to RYO cigarettes is associated with a $4.6 \%$ increase in the probability of consuming RYO cigarettes over manufactured legal cigarettes.

- Antismoking messaging is associated with a lower probability of consuming RYO cigarettes over manufactured legal cigarettes. a tobacco control measure, it is necessary to narrow the price gap between products. The results also suggest that consumers in Uruguay are likely to engage in tax avoidance by switching to RYO cigarettes rather than by switching to manufactured illegal cigarettes. However, it is still important to improve the surveillance on illegal trade, given the recent upward trend of illegal cigarette use in the capital city Montevideo.

Acknowledgements The authors would like to thank James $F$ Thrasher and Anne C K Quah for their input in the earlier drafts of this paper. The authors would also like to thank the ITC Uruguay Principal Investigators, Eduardo Bianco and Marcelo Boado, for their leadership and acknowledge their interviewers for their role in data collection. All errors are our own.

Contributors DC, CS, FJC and GTF planned the work as described in the article. $\mathrm{CS}$ and WR conducted the analyses, wrote the draft and reported the work after discussion with other authors. CS is responsible for the overall content as guarantor.

Funding The ITC Uruguay Project is supported by grants R01 CA100362, P50 CA111236 (Roswell Park Transdisciplinary Tobacco Use Research Center) and P01 CA138389 from the US National Cancer Institute, Robert Wood Johnson Foundation (045734), and Canadian Institutes of Health Research (57897, 79551, and 115016). Additional support was provided to Geoffrey T Fong from a Senior Investigator Award from the Ontario Institute for Cancer Research and a Prevention Scientist Award from the Canadian Cancer Society Research Institute. 
Competing interests None.

Patient consent Obtained.

Ethics approval All ITC Surveys were conducted with the approval of the Office of Research Ethics Committee at the University of Waterloo, Canada and the respective internal ethics board for each country.

Provenance and peer review Not commissioned; externally peer reviewed.

\section{REFERENCES}

1 Abascal W, Esteves E, Goja B, et al. Tobacco control campaign in Uruguay: a population-based trend analysis. Lancet 2012;380:1575-82.

2 Thrasher JF, Boado M, Sebrié EM, et al. Smoke-free policies and the social acceptability of smoking in Uruguay and Mexico: findings from the International Tobacco Control Policy Evaluation Project. Nicotine Tob Res 200911:591-9.

3 Canadian Cancer Society. Cigarette package health: warnings-international status report. 3rd edn. Toronto, Ontario: Canadian Cancer Society, 2012.

4 Chaloupka FJ, Kostova D, Shang C. Cigarette excise tax structure and cigarette prices: evidence from the global adult Tobacco Survey and the U S National Adult Tobacco Survey. Nicotine Tob Res 2014;16(Suppl 1):3-9.

5 Eriksen M, MacKay J, Ross H. The tobacco atlas. Atlanta, GA: American Cancer Society, 2012.

6 Shang C, Chaloupka FJ, Zahra N, et al. The distribution of cigarette prices under different tax structures: findings from the International Tobacco Control Policy Evaluation (ITC) Project. Tob Control 2014;23:i23-9.

7 Kostova D, Ross $H$, Blecher $E$, et al. Is youth smoking responsive to cigarette prices? Evidence from low- and middle-income countries. Tob Control 2011;20:419-24.

8 Kostova D, Tesche J, Perucic A, et al. Exploring the relationship between cigarette prices and smoking among adults: a cross-country study of low- and middle-income nations. Nicotine Tob Res 2014;16(Supp 1):S10-15.

9 Nikaj S, Chaloupka FJ. The effect of prices on cigarette use among youths in the global youth tobacco survey. Nicotine Tob Res 2014;16(Supp 1):S16-23.

10 Shang C, Chaloupka FJ, Kostova D. Who quits? An overview of quitters in low- and middle-income countries. Nicotine Tob Res 2014;16(Supp 1):S44-55.

11 Harris JE, Balsa Al, Triunfo P. Tobacco control campaign in Uruguay: impact on smoking cessation during pregnancy. NBER Working Paper No. 198782014.

12 Cornelius ME, Driezen P, Fong GT, et al. Trends in the use of premium and discount cigarette brands: findings from the ITC US Surveys (2002-2011). Tob Control 2014;23:i48-53.

13 Cummings $\mathrm{KM}$, Hyland $\mathrm{A}$, Lewit $\mathrm{E}$, et al. Use of discount cigarettes by smokers in 20 communities in the United States, 1988-1993. Tob Control 1997;6(Suppl 2): S25-30.

14 Cummings KM, Hyland A, Lewit E, et al. Discrepancies in cigarette brand sales and adult market share: are new teen smokers filling the gap? Tob Control 1997;6 (Suppl 2):S38-43.

15 Hanewinke IR, Isensee B. Five in a row-reactions of smokers to tobacco tax increases: population-based cross-sectional studies in Germany 2001-2006. Tob Control 2007; 16:34-7.

16 Hyland A, Laux FL, Higbee C, et al. Cigarette purchase patterns in four countries and the relationship with cessation: findings from the International Tobacco Contro (ITC) Four Country Survey. Tob Control 2006;15(Suppl 3):iii59-64.

17 Guindon GE, Driezen P, Chaloupka FJ, et al. Cigarette tax avoidance and evasion: findings from the International Tobacco Control Policy Evaluation (ITC) Project. Tob Control 2014;23:i13-22.
18 Merriman D. The micro-geography of tax avoidance: evidence from littered cigarette packs in Chicago. Am Econ J Econ Policy 2010;2:61-84.

19 White JS, Li J, Hu T-wei, et al. The effect of cigarette prices on brand-switching in China: a longitudinal analysis of data from the ITC China Survey. Tob Control 2014;23:i54-60.

20 Nargis N, Chaloupka FJ, Fong GT, et al. The choice of discount brand cigarettes: a comparative analysis of International Tobacco Control surveys in Canada and the USA (2002-2005). Tob Control 2014;23:i86-96.

21 Sáenz de Miera Juárez B, Thrasher JF, Reynales Shigematsu LM, et al. Tax, price and cigarette brand preferences: a longitudinal study of adult smokers from the ITC Mexico Survey. Tob Control 2014;23:i80-5.

22 Oshfeldt RL, Boyle RG. Tobacco excise taxes and rates of smokeless tobacco use in the US: an exploratory ecological analysis. Tob Control 1994;3:316-23.

23 Ohsfeldt RL, Boyle RG, Capilouto El. Effects of tobacco excise taxes on the use of smokeless tobacco products. Health Econ 1997;6:525-31.

24 Ohsfeldt RL, Boyle RG, Capilouto El. Tobacco taxes, smoking restrictions, and tobacco use. NBER Working Paper No.6486 1998.

25 Tsai YW, Yang CL, Chen CS, et al. The effect of Taiwan's tax-induced increases in cigarette prices on brand-switching and the consumption of cigarettes. Health Econ 2005; 14:627-41.

26 Young D, Borland R, Hammond D, et al. Prevalence and attributes of roll-your-own smokers in the International Tobacco Control (ITC) Four Country Survey. Tob Control 2006;15(Suppl 3);iii76-82.

27 Kostova D, Chaloupka FJ, Yurekli A, et al. A cross-country study of cigarette prices and affordability: evidence from the Global Adult Tobacco Survey. Tob Control 2014;23:e3.

28 Chaloupka FJ, Yurekli A, Fong GT. Tobacco taxes as a tobacco control strategy. Tob Control 2012;21:172-80.

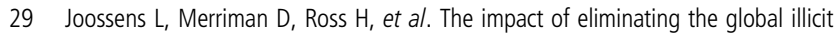
cigarette trade on health and revenue. Addiction 2010;105:1640-9.

30 Ramos A, Curti D. Economy of tobacco control in Southern Cone Common Market countries and affiliated states: Uruguay. Washington DC: Pan American Health Organization, 2006.

31 Fong GT, Cummings KM, Borland R, et al. The conceptual framework of the International Tobacco Control (ITC) Policy Evaluation Project. Tob Control 2006;15 (Suppl 3):iii3-11.

32 Thompson ME, Fong GT, Hammond D, et al. Methods of the International Tobacco Control (ITC) Four Country Survey. Tob Control 2006;15(Suppl 3):iii12-18.

33 ITC Project (August 2012). ITC Uruguay National Report. Findings from the Wave 1 to 3 Surveys (2006-2011). University of Waterloo, Waterloo, Ontario, Canada; Centro de Investigacion para la Epidemia del Tabaquismo (CIET Uruguay); Universidad de la Republica, Facultad de Ciencias Sociales.

34 Euromonitor International. Tobacco in Uruguay. October 2013.

35 Euromonitor International. Cigarettes in Uruguay. October 2013.

36 IARC Handbooks of Cancer Prevention, Tobacco Control, Vol. 12: Methods for Evaluating Tobacco Control Policies (2008: Lyon, France). http://www.iarc.fr/en/ publications/pdfs-online/prev/handbook12/Tobacco_vol12_5A.pdf, (accessed 27 Sep 2014).

37 WHO, 2010. Economics of tobacco toolkit: economic analysis of demand using data from the Global Adult Tobacco Survey (GATS). http://whqlibdoc.who.int/publications/ 2010/9789241500166_eng.pdf (accessed 27 Sep 2014).

38 Wood DM, Mould MG, Ong SBY, et al. "Pack year" smoking histories: what about patients who use loose tobacco? Tob Control 2005;14:141-2.

39 Zegar SL, Liang KY, Albert PS. Models for longitudinal data: a generalized estimating equation approach. Biometrics 1988;44:1049-60. 